\title{
Pemilihan Kepala/Wali Desa/Nagari Dengan Sistem $E$-Voting Di Kabupaten Agam Provinsi Sumatera Barat
}

\author{
Muhammad Irham ${ }^{1}$, Miracle Soplanit ${ }^{2}$ \\ ${ }^{1}$ Dosen Fakultas Hukum Universitas Pattimura \\ E-mail: irhamirham45@yahoo.co.id \\ ${ }^{2}$ Dosen Fakultas Hukum Universitas Pattimura \\ E-mail: irasoplanit@gmail.com
}

\begin{abstract}
Village head election must be continuously developed and adapted to the development of the community in the village. The Indonesian nation has stated clearly in the constitution of the 1945 Constitution of the Republic of Indonesia, the fourth paragraph which is the purpose of national and state life "..... protecting the whole Indonesian nation and the entire Indonesian blood sphere, and to promote general welfare, educating the life of the nation ". In 2017, 28 Nagari in Agam District will carry out the election of Head/Village Guard/Nagari. The elections will be held on 16, 19, 22, 25 and 29 July 2017, with a total of 128,000 voters, with an E-voting system. Through the e-voting system in the selection of Wali Nagari (Pilwana) it has made it easier for the villagers/nagari in choosing, and the potential for cheating is less than the paper voting system.
\end{abstract}

Keywords: election, village head, e-voting

\section{A. PENDAHULUAN.}

Penyenggaraan pemilihan kepala Desa/Nagari di daerah haruslah sesuai dengan karekterisitik masyarakat setempat adalah dalam rangka untuk mewujudkan penyelenggaraan pemilihan kepala Desa yang jujur adil, bermanfaat, serta untuk memberikan pendidikan politik yang demokratis kepada masyarakat, yang untuk selanjutnya akan meningkatkan kepercayaan masyarakat kepada pemimpinnya, oleh karenanya pemeilihan Kepala Desa harus secara terus menerus dikembangakan dan disesuaikan dengan perkembangan masyarakat di daerah atau desa. Bangsa Indonesia telah menyatakan dengan tegas hal ini didalam (konstitusi) pembukaan UUD NKRI Tahun 1945, Alinea ke-IV yang merupakan tujuan kehidupan berbangsa dan bernegara yakni “...... melindungi segenap bangsa Indonesia dan seluruh tumpah darah Indonesia, dan untuk memajukan kesejahteraan umum, mencerdaskan kehidupan bangsa". 
Berikutnya didalam sistem demokrasi di Indonesia, masyarakat berhak, bahkan wajib berpolitik untuk menentukan masa depannya, ikut berperan membuat peraturan perundang-undangan (hukum) serta mengawasi pelaksanaanya. Hukum di Indonesia dibentuk dalam wujud peraturan perundang-undangan, maka setiap orang yang mendiami daerah-daerah yang berada dalam wilayah Republik Indonesia harus tunduk padanya. Selanjutnya dari sudut politik, orang tidak hanya melihat pada pelaksanaan hukum an sich, akan tetapi juga mempertimbangkan akibat-akibat suatu keputusan yang berlandaskan hukum pada kepentingan masyarakat, bangsa dan Negara. ${ }^{1}$

Oleh karenanya daerah-daerah yang ada di Indonesia, sebagai satu kesatuan masyarakat hukum yang mempunyai otonomi, berwenang mengatur dan mengurus daerahnya sesuai dengan aspirasi dan kepentingan masyarakatnya. Kewenangan daerah tersebut dimaksudkan dalam rangka memberikan ruang yang lebih luas kepada daerah untuk mengatur dan mengurus warganya sesuai dengan kearifan lokal yang ada, dengan tetap mempertimbangkan kepentingan nasional. Dengan demikian akan tercipta keseimbangan antara kepentingan nasional yang sinergi dengan kondisi, kekhasanan daerah, serta kearifan lokal dalam penyelnggaraan pemerintahan. ${ }^{2}$

Selanjutnya pemerintahan daerah berdasarkan ketentuan Pasal 1 Angka 2 UU Nomor 23 Tahun 2014 tentang pemerintahan daerah yang menyatakan bahwa: "Pemerintahan daerah adalah

\footnotetext{
1 Zainuddin Ali, 2009, Sosiologi Hukum, Sinar Grafika, Cetakan Kelima, Jakarta, hlm.34-35.

2 Victor Juzuf Sedubun, 2016, Pembentukan\&Pengawasan Peraturan Daerah Yang berciri Khas Daerah, Deepublish, Yogyakarta, hlm.58-59.
}

penyenggara urusan pemerintahan oleh pemerintah daerah dan dewan perwakilan rakyat daerah menurut asas otonomi dan tugas pembantuan dengan prinsip otonomi seluas-luasnya dalam sistem dan prinsip Negara Kesatuan Republik Indonesia sebagaimana dimaksud dalam Undang-Undang Dasar Negara Republik Indonesia Tahun 1945". Ketentuan Pasal 1 angka 2 diatas mengandung makna bahwa pemerintahan daerah terdiri dari pemerintah daerah dan Dewan Perwakilan Rakyat Daerah (DPRD) yang menyenggarakan urusan pemerintahan. Pemerinthan daerah yang dimaksud adalah Gubernur sebagai kepala daerah provinsi sekaligus wakil pemerintah pusat, dan Bupati/Walikota sebagai kepala daerah di Kabupaten/Kota. ${ }^{3}$ Dengan demikian Bupati bersama-sama dengan DPRD Kabupaten dapat membuat Perda yang berkaitan dengan pemilihan Kepala Desa.

Berikutnya pemilihan Kepala Desa berdasarkan Undang-Undang Nomor 6 Tahun 2014 tentang Desa, pada Pasal 31 Ayat (1) dan (2) ditegaskan Pemilihan Kepala Desa dilaksanakan secara serentak di seluruh wilayah Kabupaten/Kota. Pada Ayat dijelaskan bahwa Pemerintahan Daerah Kabupaten/Kota menetapkan kebijakan pelaksanaan pemilihan Kepala Desa secara serentak sebagaimana dimaksud pada ayat (1) dengan Peraturan Daerah Kabupaten/Kota. Berikutnya pada Pasal 32 ayat (1) juga dinyatakan bahwa Badan Permusyawaratan Desa memberitahukan kepada Kepala Desa mengenai akan berakhirnya masa jabatan Kepala Desa secara tertulis 6 (enam) bulan sebelum masa jabatannya berakhir. dan pada Ayat (2) Badan Permusyawaratan Desa membentuk panitia pemilihan Kepala Desa. Pada Ayat (3) Panitia pemilihan Kepala Desa

\footnotetext{
3 Ibid.,
} 
sebagaimana dimaksud pada ayat (2) bersifat mandiri dan tidak memihak. (4) Panitia pemilihan Kepala Desa sebagaimana dimaksud pada ayat (3) terdiri atas unsur perangkat Desa, lembaga kemasyarakatan, dan tokoh masyarakat Desa.

Menindaklanjuti hal tersebut diatas, maka pemerintah Kabupaten Agam Provinsi Sumatera Barat telah mengeluarkan Peraturan Daerah (Perda) Nomor 3 tahun 2016 tentang Pemilihan, Pengangkatan dan Pemberhentian Wali Nagari sebagaimana telah diubah dengan Perda Nomor 12 Tahun 2016 dan Perda Nomor 13 Tahun 2016 tentang Pengangkatan dan Pemberhentian Perangkat Nagari, dimana Perda tersebut juga mengatur tentang tatacara Pengangkatan dan Pemberhentian Perangkat Nagari/Desa dengan sistem $E$-Voting.

\section{B. PEMBAHASAN}

Salah satu materi penting yang diatur dalam UU Nomor 23 Tahun 2014 tentang Pemerintahan Daerah dan UU Nomor 6 Tahun 2014 tentang Desa adalah soal keberadaan organisasi pemerintahan desa yang terdiri dari Kepala Desa dan Lembaga Perwakilan Desa. Semangat yang terkandung ialah keberadaan desa sebagai self governing community yang bersifat otonom atau mandiri. Bahkan dapat dikatakan bahwa daya jangkau organisasi Negara secara structural hanya samapai pada ting at kecamatan, sedangkan di bawah kecamatan dianggap sebagai wilayah otonom yang diserahkan pengaturan dan pembinaannya kepada dinamika yang hidup dalam masyarakat itu sendiri secara otonom. Oleh karena itu, tradisi pemerintahan desa seperti yang hidup di Sumatera Barat, misalnya, yang dikenal dengan nama sistem pemerintahan nagari dapat dihidupkan kembali penataanya sebagaimana mestinya. $^{4}$

Dengan demikian pemilihan kepala desa (selanjutnya disebut nagari) menjadi suatu hal yang sangat penting, baik proses awal, tahap-tahapan pemilihannya, indenpendensi petugas pelaksananya, hak pilih dan dipilih masyarakatnya, keabsahan suara, keakuratan hasil pemilihan dan lain sebagainya. Untuk mengatasi berbagai persoalan tersebut maka pemerintahan Kabupaten Agam Provinsi Sumatera Barat telah mengeluarkan Perda Kabupaten Agam Nomor 3 tahun 2016 tentang pemilihan, pengangkatan dan pemberhentian Wali Nagari sebagaimana telah diubah dengan Perda Nomor 12 Tahun 2016 dan Perda Nomor 13 Tahun 2016 tentang Pengangkatan dan Pemberhentian Perangkat Nagari, dimana Perda tersebut juga mengatur tentang tatacara Pengangkatan dan Pemberhentian Wali Nagari dengan sistem E-Voting.

\section{Peserta Pemilihan Kepala Desa (Wali Nagari)}

Pada tahun 2017, 28 nagari di Kabupaten Agam akan melaksanakan pemilihan wali nagari. Pemilihan akan dilaksanakan serentak. Nagari dimaksud adalah Tiku Utara, Sitanang, Bawan, Salareh Aia, Duo Koto, Paninjauan, Koto Malintang, Malalak Barat, Malalak Timur, Balingka, Sianok Anam Suku, Koto Gadang, Taluak IV Suku, Padang Laweh, Kubang Putiah dan Sungai Tanang. Batu Palano, Sungai Pua, Padang Laweh, Balai Gurah, Biaro Gadang, Lambah, Kapau, Gadut, Pasia Laweh, Nan Tujuah dan Nagari Kamang Hilia. Pemilihan Wali Nagari (Pilwana) dilaksanakan secara serentak di Kabupaten Agam sudah

\footnotetext{
4 Jimly Asshiddiqie, 2010, Konstitusi \& Konstitusionalisme Indonesia, Edisi Kedua, Cetakan Pertama, Sinar Grafika, Jakarta, hlm. 242.
} 
menggunakan sistem $e$-voting. Dalam tahapan sosialisasi e-voting tersebut melibatkan pihak Dinas Kependudukan Catatan Sipil, dinas terkait, serta bekerjasama dengan Badan Pengkajian dan Peneran Teknologi (BPPT). Sistem e-voting ini berdasarkan Undang-undang Nomor 6 tahun 2014, tentang Desa beserta peraturan pelaksanaannya, dan Perda Nomor 3 tahun 2016 tentang pemilihan, pengangkatan dan pemberhentian Wali Nagari.

Selanjutnya Sekretaris Dinas Pemberdayaan Masyarakat dan Nagari (DPMN) Agam, Gusri Noval di Lubuk Basung, mengatakan, tahapan pemilihan Kepala/wali Desa/Nagari tersebut telah dilakukan dan sudah ada sebagian nagari yang telah menetapkan calon wali nagari. Dari 28 nagari yang akan melaksanakan pemilihan wali nagari, terdapat 22 nagari yang sudah menetapkan calon wali nagari dan telah menetapkan nomor urut. Sedangkan enam nagari yakni, Nagari Panampuang, Kubang Putiah, Taluak, Ladang Laweh, Sungai Janiah dan Gaduik belum menetapkan calon wali nagari karena jumlah bakal calon yang mendaftar masih kurang dari dua calon. Apabila calon masih kurang dari dua, maka pemilihan ini akan ditunda pada pemilihan serentak tahap dua pada 2019.

Pemilihan serentak itu akan menggunakan 50 unit perangkat seperti komputer beserta perangkat lain, mesin pencetak (printer), aplikasi e-voting, alat pembaca kartu tanda penduduk dan lainnya. Sementara mekanisme pelaksanaan pemilihan wali nagari serentak nantinya tidak satu hari karena jumlah TPS di 28 nagari ini sebanyak 203 unit. Namun akan dilanjutkan pada hari berikutnya mengingat jumlah alat e-voting masih terbatas. Pemilihan akan dilaksanakan pada 16, 19, 22, 25 dan 29 Juli 2017, dengan jumlah pemilih di 28 nagari tersebut ini sebanyak 128.000, dimana panitia pemilihan nagari sedang melakukan verifikasi pemilih. Selanjutnya anggota DPRD Agam, Jondra Marjaya berharap panitia melakukan tahapan pemilihan sebaik mungkin agar tahapan dapat berjalan dengan baik. Selain itu, panitia juga jeli melakukan verifikasi syarat yang diajukan oleh bakal calon. "Dengan cara ini maka tidak ada calon yang tidak menerima hasil pemilihan nanti," katanya. ${ }^{5}$

\section{Pelaksanaan Pemilihan Kepala Desa (Wali Nagari)}

Pelaksanaan pemilihan wali nagari (Pilwana) tahap I yang berlangsung di dua kecamatan di Kabupaten Agam, yakni Kecamatan Ampek Nagari dan Kecamatan Palembayan pada Minggu (16/7) berlangsung aman dan lancer, kehadiran pemilih pun lumayan. Menurut Kepala Dinas Pemberdayaan Masyarakat Nagari (DPMN) Kabupaten Agam, Rahmad Lasmono saat ditemui Selasa (18/7), di Kecamatan Ampek Nagari, ada dua nagari yang melaksanakan Pilwana, yakni Sitanang dan Bawan. Kehadiran pemilih sangat bervariasi. $^{6}$

Di Nagari Bawan misalnya, kehadiran pemilih ke TPS sekitar 36 persen. Suara terbanyak, dari 20 TPS, dikumpulkan Calon Nomor urut 2, Kamiruddin (1.658), disusul Calon Nomor nomor urut 3, Moh. Abdi (1198). Di Nagari Sitanang, suara terbanyak diraih Calon Wali Nagari Nomor Urut 3, Afrizal (512), disusul Nomor Urut 1, Syahrizaul (362), dari jumlah pemilih yang hadir 1.026. Kehadiran pemilih

\footnotetext{
5 http://www.antarasumbar.com/berita/202893/ pemilihan-wali-nagari-kabupaten-agam-guna kan-e-voting.html, dikunjungi pada Tanggal 13 September 2017, pukul 14.30 WIT

6 http://pekanbaru.tribunnews.com/2017/07/19/ pilwana-agam-kehadiran-pemilih-dibawah-5 0-persen, dikunjungi pada Tanggal 13 September 2017, pukul 15.30 WIT
} 
dari 2 TPS di nagari tersebut mencapai 65,06 persen dari total pemilih sesuai Daftar Pemilih Tetap (DPT), 1.577 orang. Sedangkan dari Silareh Aia, selanjutnya did Kecamatan Palembayan, peraih suara terbanyak adalah Iron Maria, dengan 1.200 suara. Namun tidak diperoleh berapa jumlah pemilih sesuai DPT dan berapa kehadiran pemilih ke TPS. Tetapi diperoleh informasi, kalau kehadiran pemilih di 19 TPS yang ada, hanya sekitar 39 persen. $^{7}$

Selanjutnya Pemilihan Wali Nagari (Pilwana) Serentak ini dilakukan lima tahap. Tahap pertama dimulai Minggu Tanggal 16 Juli 2017 di 3 Nagari, yakni Nagari Bawan, Nagari Sitanang dan Nagari Salareh Aia. Tahap kedua dilakukan pada Rabu Tanggal 19 Juli 2017 di 9 nagari yaitu, Nagari Tiku Utara, Nagari Duo Koto, Nagari Paninjauan, Nagari Koto Malintang, Nagari Balingka, Nagari Sianok, Nagari Koto Gadang, Nagari Malalak Timur dan Nagari Malalak Barat. Tahap ketiga dilaksanakan pada Sabtu Tanggal 22 Juli 2017 di 7 nagari, yaitu Nagari Padanglua, Nagari Kubang Putiah, Nagari Sungai Tanang, Nagari Taluak Ampek Suku, Nagari Ladang Laweh, Nagari Gaduik, dan Nagari Kapau. Tahap keempat digelar pada Selasa Tanggal 25 Juli 2017 di 4 nagari, yakni Nagari Batu Palano, Nagari Padang Laweh, Nagari Sungai Pua, Nagari Nan Tujuah, dan Nagari Pasia Laweh. Sementara Pilwana tahap kelima, Sabtu Tanggal 29 Juli 2017 dilaksanakan di Nagari Balai Gurah, Nagari Biaro, Nagari Lambah, dan Nagari Kamang Hilia. Kata Bapak Rince, S.H, selaku ketua penyelenggara pemilihan Wali Nagari Kubang Putiah. ${ }^{8}$

Rince melanjutkan bawa hasil

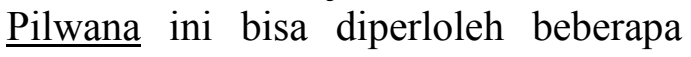

7 Ibid.,

8 Wawancara dilakuakan Pada Tanggal 23 Agustus 2017, Pukul 15.30 WIB menit setelah pemilihan, karena kita menggunakan E-voting,"ujarnya. Rince menjelaskan, sebelum pelaksanaan Pilwana, pihaknya sudah melakukan sosialisasi dan simulasi pelaksanaan Pilwana kepada warga. Dengan cara ini, maka pemilih tidak merasa kesulitan, dan pada saat pelaksanaannya Pilwana ini dapat berjalan dengan lancar dan aman. Ia menjelaskan, terwujudnya Pilwana Badunsanak/bersaudara ini merupakan komitmen dan cita-cita Bupati Agam Indra Catri. Bupati berharap dalam proses Pilwana dari awal sampai selesai dapat berjalan dengan lancar, aman dan sukses. ${ }^{9}$

Selanjutnya berdasarkan hasil wawancara dengan beberapa masyarakat di wilayah Kabupaten Agam Provinsi Sumatera Barat, dapat diperoleh informasi bahwa melalui sistem E-voting dalam Pilwana tersebut telah memberikan kemudahan bagi masyarakat dalam memilih, dan kemungkinan potensi kecurangannya lebih kecil dibandingkan dengan sistem pemungutan suara lewat kertas. ${ }^{10}$

Hal senada juga disampaikan oleh ketua Badan Musyawarah Nagari/Desa (Bamus) Nagari Kubang Putiah Zul Fami yang mengatakan bahwa, memang diawal sosialisasi maupun awal pelaksanaan pemilihan banyak masyaraklat yang gugup, sebab yang dihadapapkan mereka adalah alat-alat mesin seperti mesin ATM dan komputer dimana bagi pemilih yang berusia diatas 60 Tahun Hal ini sangat menyulitkan diawalnya, tapi ketika mereka telah mencobanya, meraka semuanya berkata hal ini sangat mudah dan sangat membantu mereka, masyarakat juga menyambut positif pemilihan wali nagari dengan sistem E-Voting ini

\footnotetext{
9 Ibid.,

${ }^{10}$ http://www.sumbarsatu.com/berita/14315-aga m-laksanakan-pemilihan-wali-nagari-serenta k-2017, dikunjungi pada Tanggal 13 September 2017, pukul 14.05 WIT
} 
seperti yang disampaikan oleh Bapak Datuk Mukni dan Bapak Indra Noveri warga kubu tanjung, ${ }^{11}$ pernyataaan yang hampir sama juga disampaikan oleh Fitria warga nagari Batu Tabah Kabupaten Agam. ${ }^{12}$

\section{PE N U T U P}

Tahun 2017, 28 nagari di Kabupaten Provinsi sumatera Barat telah melaksanakan pemilihan Wali Nagari (Kepala Desa) dengan Sistem E-Voting, pemilihan Wali Nagari (Pilwana) ini didasari pada Perda Kabupaten Agam Nomor 3 tahun 2016 tentang pemilihan, pengangkatan dan pemberhentian Wali Nagari sebagaimana telah diubah dengan Perda Nomor 12 Tahun 2016 dan Perda Nomor 13 Tahun 2016 tentang Pengangkatan dan Pemberhentian Perangkat Nagari, dimana Perda tersebut juga mengatur tentang tatacara Pengangkatan dan Pemberhentian Wali Nagari dengan sistem E-Voting. Dalam pelaksanaan Pilwana dengan sistem E-Voting tersebut telah memberikan kemudahan bagi masyarakat dalam memilih, dan kemungkinan potensi kecurangannya lebih kecil dibandingkan dengan sistem pemungutan suara lewat kertas.

\section{DAFTAR PUSTAKA}

Jimly Asshiddiqie, 2010, Konstitusi \& Konstitusionalisme Indonesia, Edisi Kedua, Cetakan Pertama, Sinar Grafika, Jakarta.

11 Wawancara dengan Bapak Zul Fami, Bapak Datuk Mukni dan Bapak Indra Noveri, dilakuakan Pada Tanggal 27 Agustus 2017, Pukul 13.30 WIB

12 Wawancara dengan Ibu Fitria dilakuakan Pada Tanggal 4 September 2017, Pukul 10.00 WIB
Peter Mahmud Marzuki, 2011, Penelitian Hukum, Kencana, Jakarta.

Victor Juzuf Sedubun, 2016, Pembentukan\&Pengawasan Peraturan Daerah Yang berciri Khas Daerah, Deepublish, Yogyakarta.

Zainuddin Ali, 2009, Sosiologi Hukum, Sinar Grafika, Cetakan Kelima, Jakarta.

, 2009, Metode Penelitian

Hukum, Sinar Grafika, Jakarta. 